Malgorzata Żytko

ORCID: 0000-0002-1191-9894

Uniwersytet Warszawski

mzytko@uw.edu.pl https://doi.org/10.26881/pwe.2020.49.08

\title{
Wczesna edukacja - między standaryzacją a upodmiotowieniem
}

\author{
Gdy wygladasz tylko tego, czego się spodziewasz, \\ gdy cenisz tylko wyznaczone cele, wiele tracisz.
}

(Dahlberg i in. 2013)

\begin{abstract}
Summary
Early education - between standarization and subjectification

The article attempts to answer the question: why standardization of early education can limit the development of children and disintegrate the learning process? The main topic is focused on the issue of standardization in early childhood education. The goals of education, core curriculum, expected developmental effects and learning outcomes are most often standardized. The standardization process has specific consequences that affect the quality of education and development opportunities for students. The effect of this approach, especially close to politicians, stakeholders, is limited variety of educational approaches, fragmentation, depersonalization of education and subordinating it to standards and set goals. All these activities should favor the control of results achieved. The destination is defined at the beginning of the education process. The achievement of "experts" "aims is the basis for assessments of the value of the teacher's work and the effectiveness of educational institutions.
\end{abstract}

Keywords: standardization, diagnosis, normalization, child development, subjectivity, autonomy

Słowa kluczowe: standaryzacja, diagnoza, normalizacja, rozwój dziecka, podmiotowość, autonomia

Motto artykułu zachęca do refleksji w kontekście myślenia o współczesnych celach i zadaniach edukacji. Przy pierwszej analizie wydaje się, że zawarta jest tutaj sprzeczność. Przecież często w procesie kształcenia nauczycieli podkreśla się, że wyznaczenie jasnego celu lekcji, działań podejmowanych z uczniami jest ważne, aby mieć świadomość tego, do czego dążymy, bo jesteśmy rozliczani z efektów kształcenia. Dlaczego więc konkretne oczekiwanie efektu ma się wiązać z negatywnym skutkiem, co tracimy jako nauczyciele, wyznaczając sobie precyzyjnie cele naszych działań z uczniami, podporządkowując pracę pedagogiczną zapisom podstawy programowej, standardom i normom, które „eksperci” określili w naszym imieniu i zadekretowali ich realizację? Tutaj warto przytoczyć kolejny 
cytat: „Dominujący język wczesnego dzieciństwa sam generuje pytania. Jak mierzymy jakość? Jakie programy są najbardziej opłacalne? Jakich standardów potrzebujemy? Jak najlepiej osiągnąc pożądane rezultaty? Co działa? Wszystkie te pytania łączy techniczny charakter i perspektywa zarządzania. Są one wyrazem poszukiwania technik, które zagwarantują standaryzację, przewidywalność i kontrolę. Wskazują na dążenie do znalezienia metod, które pozwolą zredukować świat do zestawu obiektywnych stwierdzeń faktu, niezależnych od stwierdzeń wartości i potrzeby dokonywania ocen" (Dahlberg i in. 2013: 44). Taki język dotyczący wczesnej edukacji eksponuje pewność przyjętych rozwiązań, oczekiwanie bezwarunkowej efektywności, techniczne, instrumentalne podejście. Niewiele miejsca zostaje na wątpliwości, alternatywne rozwiązania czy spojrzenie z lokalnej perspektywy na potrzeby danej społeczności szkolnej czy przedszkolnej. Nawet jeśli pojawia się możliwość alternatywnego działania, to musi być ono „wciśnięte” w sztywne ramy podstawy programowej, zadekretowanych z góry treści, a czasem także określonych sposobów działania zalecanych w oficjalnych dokumentach. Zdaniem Doroty Klus-Stańskiej: „,...) normalizujące standardy, które określają obszary diagnoz szkolnych, prowadzą do segregacji uczniów, determinują trajektorie ich szkolnych - a w konsekwencji całożyciowych biografii. Wszystko to, zatwierdzone autorytetem instytucji, nadaje tym »orzekającym rozpoznaniom « status metody naukowej i atrybut niedyskutowalności" (Klus-Stańska 2015: 12).

\section{Dwie tendencje w ujęciu celów edukacji}

Pierwsza z nich, zdecydowanie powszechniejsza i mająca więcej zwolenników, to standaryzacja praktyki edukacyjnej. Służą temu celowi odgórnie opracowywane podstawy programowe ściśle regulujące: zasady funkcjonowania szkoły i przedszkola, systemy oceniania efektywności kształcenia, ze szczególnym uwzględnieniem testów krajowych i międzynarodowych, które są podporządkowane mierzalnym standardom, a także silna potrzeba sytuowania osiągnięć edukacyjnych na szczeblach rankingowej drabiny. Wśród popularnych narzędzi normalizujących edukacyjną ofertę i przygotowanych przez „ekspertów” są m.in. zestawy diagnozujące gotowość szkolną, inwentarze zachowania w klasie szkolnej, kwestionariusze do oceny adaptacji dzieci do przedszkola (por. Klus-Stańska 2015).

Efekty tego podejścia, szczególnie bliskiego politykom, gremiom zarządzającym oświatą, to: ograniczanie różnorodności podejść edukacyjnych, fragmentaryzacja, depersonalizacja edukacji, podporządkowanie jej określonym normom i wyznaczonym celom, co ma sprzyjać kontroli uzyskiwanych efektów. Punkt dojścia określa się na początku procesu edukacji, ponieważ osiągnięcie tych „eksperckich celów” jest podstawą oceny wartości pracy pedagogicznej nauczyciela i efektywności instytucji edukacyjnej. System edukacyjny działa Pod presją tych docelowych działań i lęku przed ich nie dość efektywnym zrealizowaniem.

Druga tendencja, która towarzyszy pedagogom, badaczom edukacji, psychologom i socjologom, analizującym uwarunkowania efektywnego funkcjonowania edukacji, to 
nastawienie na różnorodność, wielowymiarowość świata społecznego. W edukacji oznacza to zindywidualizowane podejście, spersonalizowane, holistyczne, uwzględniające różne style rozwoju uczniów i potrzeby edukacyjne, ujawniające się w odmiennych kontekstach i uwarunkowaniach, które tworzą specyficzną przestrzeń dla funkcjonowania edukacji (Taguchi 2010: 19). John Dewey uważał, że: „doświadczenie ludzkie nie zna kresu, póki doświadczenie jako takie nie osiągnie kresu", stwierdzenie to można interpretować jako podsumowanie alternatywnego w stosunku do standaryzacji podejścia do edukacji. Można uznać, że wyznaczenie z góry szczegółowego celu działania ogranicza poznawczy walor doświadczenia, które może przynieść nieoczekiwane odkrycie. Nawet jeśli planując doświadczenie, określa się cząstkowe cele, to jest to taki proces, podczas którego zostają one weryfikowane w trakcie doświadczenia. Dopiero po pewnym etapie doświadczeń, podsumowując działania, można sprecyzować konkretny cel, jaki się osiągnęło. Zatem $\mathrm{z}$ jednej strony dostrzega się i docenia różnorodność rozwojową uwarunkowaną lokalnym kontekstem środowiskowym i kulturowym, z drugiej zaś ta różnorodność musi zostać okiełznana i zamknięta w ramach standaryzacji i normalizacji edukacji, ale również koncepcji psychologicznych ściśle opisujących stadia rozwoju dzieci (por. Burman 2010). Efektem dominacji standaryzacyjnych procesów w edukacji jest fikcyjny obraz dziecka jako produktu systemu edukacyjnego, który jest wyabstrahowany z kontekstu środowiskowego i kulturowego. Następuje też rozdzielenie dwóch procesów: nauczania i budowania kompetencji uczącego się, uczenie się bowiem jest ujmowane jako proces odtwarzania tego, co jest zewnętrzne. Uczący się jest niejako na zewnątrz tego procesu, a nie wewnątrz aktywności edukacyjnej, którą współtworzy. Oto fragment „rozmowy” nauczyciela z dziećmi, nawiązujący do takiej praktyki edukacyjnej:

[...] N: - Jest coś takiego, czego nie ma zimą w powietrzu. Teraz są w powietrzu. Niektóre ptaki je jedzą. (...) coś, co lata w powietrzu (...) mówiliśmy o tym w tamtym tygodniu i teraz do tego wracamy...

Dz. 1: Co?

$\mathrm{N}$ : Tak, co lata teraz dookoła w powietrzu (...) jest ich bardzo dużo...

Dz. 1: Ptaki! Pszczoły! Trzmiele!

$\mathrm{N}$ : Tak, myślę o bardzo małym owadzie. Powiedziałeś...

Dz. 1: Trzmiel.

N: No tak (z wahaniem) i jakie jeszcze małe owady znamy?

Dz. 1: Pszczoły!

$\mathrm{N}$ : Hm, są jeszcze inne owady... takie, które przylatują i was gryzą. Wiesz, co to za owady?

Takie, które gryzą nas latem i potem nas swędzi?

Dz. 2: Pszczoła?

$\mathrm{N}$ : Tak, ale...(wydaje brzęczący dźwięk)

Dz. 2: Osa!

$\mathrm{N}$ : Myślę o komarach.

Dz. 2: Co...

N: Komary.

(Dahlberg i in. 2013: 110) 
Jest to ilustracja takiej relacji w procesie uczenia się, kiedy dziecko jest na zewnątrz tej pozornej interakcji, bezradne w toku prowadzenia swoistej zgadywanki, co nauczyciel miał na myśli. Traktowane jest jak obiekt oddziaływań nauczyciela, któremu wtłacza się jedną jedyną odpowiedź, nie stawia żadnych wyzwań, nie uznaje się jego prawa do samodzielnego myślenia. Dziecko nie uczestniczy w procesie uczenia się, natomiast bierze udział w instruktażowej wymianie: pytanie nauczyciela - odpowiedź ucznia - ocenianie nauczyciela. Charakterystyczne jest zdziwienie dziecka wyczuwalne w końcowej części tej komunikacyjnej wymiany, gdy okazuje się, że właśnie ta (i tylko ta) odpowiedź była oczekiwana i uznana za poprawną. To tylko jeden z wielu przykładów, jak w codziennej praktyce edukacyjnej hamuje się potencjał rozwojowy dzieci, gdy cel jest zaplanowany i znany jedynie nauczycielowi. W ten sposób dokonuje się też proces fragmentaryzacji doświadczeń i wiedzy dzieci, tworzący sztuczny obszar wiadomości oczekiwanych i akceptowanych przez nauczyciela w szkole, który nie ma związku z osobistą wiedzą uczniów. Następuje de facto proces dezintegracji procesu uczenia się z wyraźnym oddzieleniem uczenia się pozaszkolnego.

A oto kolejny zapis komunikacji nauczyciela z dziećmi podczas rozwiązywania zadania matematycznego w klasie III:

Na zimowisko wyjedzie pociągiem 135 dzieci. Ile trzeba zarezerwować ośmioosobowych przedziałów, by każde dziecko miało miejsce siedzące?

N: Dobrze, ciiiii... Jeszcze przeczyta dziewczynka, proszę Marta!

UM: Na zimowisko wyjedzie pociągiem 135 dzieci. Ile trzeba zarezerwować ośmioosobowych przedziałów, by każde dziecko miało miejsce siedzące?

$\mathrm{N}$ : Tak, bardzo proszę, jakie dane mamy tutaj w tym zadaniu? Czego się dowiedzieliśmy? Jak (...), co takiego tam jest w treści, co przyda nam się do rozwiązania tego zadania? Proszę, Damian? Jakie dane znalazłeś? Jaką liczbę znalazłeś?

UD: $135 \ldots$

$\mathrm{N}$ : Ale głośno, wyraźnie.

UO: Znalazłem liczbę $135 \ldots$

N: 135 dzieci. (wzmocnionym głosem, UD stara się podążać głosem za nauczycielem) Dzieci, które trzeba przewieźć pociągiem. Dziękuję, drugą liczbę Robert. Gdzie ukryła się druga liczba? Gdzie ukryła się druga liczba?

U3: Osiem.

U4: Osiem.

$\mathrm{N}$ : Osiem, ośmioosobowych przedziałów, czyli osiem. Czyli, w każdym przedziale tego pociągu można przewieźć osiem osób. Skoro zadanie, to również pytanie! O co pyta autor? Marek.

UM: Ile trzeba zarezerwować ośmioosobowych przedziałów, by każde dziecko miało miejsce siedzące?

$\mathrm{N}$ : Czy już świta coś w głowie? Mamy jakieś rozwiązanie? Artur, proszę.

UA: 135 trzeba podzielić na osiem.

$\mathrm{N}$ : Tak i to na dodatek sposobem pisemnym.

U1: Mogę ja? 
$\mathrm{N}$ : Bardzo proszę, nie, teraz będzie troszeczkę inaczej. Posłuchajcie, uważnie słuchamy, bo pani powie tylko jeden raz. Należy za momencik otworzyć zeszyt, tak jak to zwykle robimy, napisać numer zadania, wpisać dzisiejszą datę, oczywiście i rozwiązać samodzielnie to zadanie. Dzisiaj jest 22 marca (zapisuje na tablicy).

U2: Pytanie, działanie, odpowiedź.

$\mathrm{N}$ : Właśnie, my mamy taką swoją zasadę od pierwszej klasy, że rozwiązując zadanie z treścią, robimy co?

UO: Pytanie, działanie, odpowiedź.

$\mathrm{N}$ : Olku, właśnie, cieszę się, że już się poprawiłeś. Musimy napisać co?

UO: Pytanie, działanie, odpowiedź.

N: Pytanie, działanie, odpowiedź, oczywiście numer zadania i strona musi też być. Samodzielnie, proszę bardzo zabieramy się do pracy ${ }^{1}$.

Podczas tej lekcji dzieci są instruowane (a nie uczone), jak rozwiązywać zadanie. Cechą charakterystyczną tej komunikacji z nauczycielem, podobnie jak w poprzednim przykładzie, jest również dopasowanie działania dzieci do z góry zaprojektowanej ramy metodycznej, dotyczącej rozwiązywania zadania. Przygotowano bowiem standardowy wzorzec, który zakłada, że przede wszystkim konieczne jest ścisłe pokierowanie działaniami dzieci według metodycznego schematu. Wzorzec wymaga poszukiwania w treści zadania liczb, a kiedy te liczby zostaną odnalezione, ustala się rodzaj działania arytmetycznego, które trzeba zastosować, w tym wypadku jest to dzielenie. Przy czym nauczyciel podkreśla, że to dzielenie musi być wykonane określonym sposobem - pisemnie. Nie oczekuje się od dzieci poszukiwania własnej strategii. Dzieci mają wyćwiczony pamięciowo schemat rozwiązywania zadań, wdrożony przez nauczyciela już od pierwszej klasy: pytanie, działanie, odpowiedź. Dzieci recytują tę zasadę nauczyciela, powtarzają i stosują w praktyce. W wypadku tych zajęć widać, jak w systematyczny sposób ogranicza się myślenie dziecka do powtórzenia schematu rozwiązywania zadania, który jest przejęty z zewnątrz, dziecko jest tylko depozytariuszem.

Zaprezentowany przykład komunikacji, a właściwie monologu, nauczyciela na lekcji matematyki wyraźnie wskazuje na określony model podejścia do edukacji. Konsekwencją tego modelu jest przeświadczenie, które zakłada, że uczniowie nie wiedzą, jak rozwiązać zadania, muszą więc poczekać, aż otrzymają od nauczyciela dokładną instrukcję, jak powinien przebiegać proces rozwiązania. Dopiero wtedy mogą przystąpić do ćwiczenia rozwiązywania podobnych zadań, według przyjętego nie przez nich, ale przez nauczyciela sposobu. Warto zauważyć, że od ucznia nie oczekuje się samodzielności, nauczyciel nie jest zainteresowany uczniowskimi strategiami i pomysłami rozwiązania tego zadania, natomiast czyni wiele, aby dzieci sprawnie i efektywnie zapamiętały właśnie jego sposób

1 Rozmowa zarejestrowana podczas obserwacji lekcji prowadzonych w ramach ogólnopolskich badań projektu Badanie umiejętności podstawowych uczniów klas trzecich szkoły podstawowej (2007-2010), Priorytet III. Badania uwarunkowań zróżnicowania wyników egzaminów zewnętrznych. Działanie 3.1., Decyzja Ministra Edukacji Narodowej POKL.03.02.00-00-007/07. Por. Dagiel, Żytko (red.) (2009); Dąbrowski (2013); Dąbrowski, M. Żytko (red.) (2008); Żytko (2010, 2015). 
rozwiązania - zapamiętały i powtórzyły w kolejnych zadaniach podobnego rodzaju. To nawet nie jest sposób nauczyciela, on jest raczej narzucony przez tak zwane poprawne metodycznie i znormalizowane sposoby działania. Jak zauważa Grażyna Szyling, takie nieustanne sprawdzanie przez nauczyciela dopasowania uczniów do określonego wzorca działania wytwarza u nich ,stabilny obraz tego, na czym polega uczenie się. Jego trwałym rysem jest nastawienie na udzielanie odpowiedzi oczekiwanych przez nauczyciela (lub autora podręcznika), otrzymywanie dobrych stopni i realizowanie cudzych celów (...)" (Szyling 2019: 66). Autorka określa to mianem przemocy poznawczej, która wyraża się w lekceważeniu potrzeb uczniów i zmuszaniu ich do przyjmowania cudzej perspektywy myślenia, odległej od rzeczywistości.

\section{Podstawa programowa i diagnozowanie gotowości szkolnej}

$\mathrm{Z}$ zagadnieniem standaryzacji edukacji wiąże się też konstrukcja podstawy programowej i sposób jej traktowania przez administrację oświatową i nauczycieli. Gdy program nauczania określa dokładnie jeden właściwy sposób nauczania (zazwyczaj oparty na pedagogice transmisji), skazuje wielu uczniów na porażkę, podczas gdy alternatywne metody mogłyby pomóc im odnieść sukces. Powoduje także rodzaj „,wyuczonej bezradności” wśród nauczycieli, którzy są przeszkoleni w procesie realizacji podstawy programowej i rozliczani z jej wdrażania. Nie oczekuje się od nich znalezienia najlepszych sposobów uczenia się, odpowiednich dla konkretnego ucznia. Nie zakłada się więc indywidualizacji oddziaływań edukacyjnych. Warto podkreślić, że w tym kontekście program nauczania nie jest najlepszym materiałem do standaryzacji. Powinien bowiem być tak skonstruowany, aby inspirować różnorodność działania w edukacji, a proces standaryzacji wyklucza takie możliwości lub znacząco je ogranicza. Program nauczania powinien być jednym $\mathrm{z}$ wielu narzędzi wspierania rozwoju dziecka, a nie ramą ograniczającą działania nauczyciela. Taki warunek może być spełniony, gdy podstawa programowa ma ogólny charakter, wyznacza kierunki działania, określa główne obszary efektów edukacyjnych i inspiruje do twórczego oraz autonomicznego działania nauczycieli. W tym miejscu warto przywołać fragment polskiej podstawy programowej dla I etapu edukacji w części dotyczącej osiągnięć ucznia w pisaniu:

"- pisze odręcznie, czytelnie, płynnie, zdania i tekst ciągły, w jednej linii; rozmieszcza właściwie tekst ciągły na stronie zeszytu, sprawdza i poprawia napisany tekst;

- układa i zapisuje opowiadanie złożone z 6-10 poprawnych wypowiedzeń w ramach zagadnień opracowanych podczas zajęć; opisuje np. osobę, przedmiot, element świata przyrody na podstawie własnych obserwacji lub lektury;

- pisze notatkę, życzenie, ogłoszenie, zaproszenie, podziękowanie, list; zapisuje adres nadawcy i odbiorcy; pisze krótkie teksty, wykorzystując aplikacje komputerowe;

- pisze z pamięci i ze słuchu; przestrzega poprawności ortograficznej w wyrazach poznanych i opracowanych podczas zajęć; 
- stosuje poprawnie znaki interpunkcyjne na końcu zdania i przecinki przy wyliczaniu, zapisuje poznane i najczęściej stosowane skróty, w tym skróty matematyczne;

- porządkuje wyrazy w kolejności alfabetycznej według pierwszej i drugiej litery;

- zapisuje poprawnie liczebniki oraz wybrane, poznane w trakcie zajęć pojęcia dotyczące różnych dyscyplin naukowych;

- stosuje poprawną wielkość liter w zapisie tytułów utworów, książek, poznanych nazw geograficznych, imion i nazwisk;

- układa i zapisuje zdarzenia we właściwej kolejności, układa i zapisuje plan wypowiedzi” (Rozporządzenie Ministra Edukacji Narodowej, zał. 2).

Analiza tych oczekiwanych efektów kształcenia wobec uczniów kończących I etap edukacji jest właśnie przykładem ilustrującym zjawisko zamykania rozwoju umiejętności językowych w sztywne ramy, zdominowane przekonaniem twórców tego dokumentu, że tylko tak można rozwijać u dzieci umiejętność pisania. Przeważają stwierdzenia, które wskazują na bardzo formalne, instrumentalne i promujące przede wszystkim poprawność wypowiedzi podejście do tej umiejętności. Spośród twórczych form wypowiedzi wymieniono tylko opowiadanie i wyraźnie doprecyzowano, z maksymalnie ilu zdań ma się składać, a tematyka ma dotyczyć zagadnień opracowywanych podczas zajęć. Wspomina się też w tym samym punkcie o opisywaniu osób, przedmiotów czy świata przyrody. Poza tym wśród oczekiwanych umiejętności w zakresie pisania wymienia się poprawność posługiwania się językiem pisanym w zakresie składni, gramatyki i ortografii. Nie oczekuje się spontanicznych, twórczych wypowiedzi, pisania nie tylko na tematy związane z lekcjami szkolnymi, ale inspirowane wyobraźnią, doświadczeniami dzieci, pytaniami, jakie sobie stawiają. Traktowanie podstawy programowej jako głównego przewodnika w pracy nauczyciela, celu samego w sobie, może budzić uzasadnione wątpliwości co do interpretacji głównego celu edukacyjnego. Nauczyciel rozliczany z realizacji takiej podstawy staje się niejako jej „niewolnikiem”, gdy nie potrafi dostrzec pola do samodzielnego działania.

Przy dominacji normatywnego podejścia do edukacji i podstaw programowych, szczegółowo określających ramy edukacyjnych działań, pojęcie socjalizacji zastępuje planowa inkulturacja, wspólna dla wszystkich dzieci. Są one niejako „dodawane” do istniejących lub tworzonych ram. Gunilla Dahlberg, Peter Moss i Alan Pence (2013) opisują podejście związane z pedagogiką normalizacyjną, określaną też jako neutralną kulturowo i środowiskowo, na przykładzie obserwacji rozwoju dzieci. Dokonuje się obserwacji w odniesieniu do przyjętych z góry kategorii zbudowanych przez „ekspertów”. Ustalenie, co w danym wieku ma charakteryzować „normalnie” rozwijające się dziecko, to nic innego jak proces dopasowywania jego rozwoju do określonych standardów. Ułatwia to niewątpliwie mierzenie efektów rozwojowych, ale jednocześnie wyniki tej obserwacji są ograniczone do przyjętego schematu, a to tylko część obrazu funkcjonowania dziecka, daleka od holistycznego ujęcia. Takim widocznym przykładem zamykania rozwoju dziecka w określonych ramach jest badanie gotowości szkolnej. Po dokonaniu analizy dostępnych nauczycielom kilku narzędzi do badania gotowości szkolnej można zilustrować ten proces. Podczas takiego badania charakteryzuje się rozwój dziecka w różnych sferach, ważnych, 
zdaniem autorów, dla pomyślnego rozpoczęcia nauki szkolnej. Oto przykład dotyczący oceny rozwoju dziecka:

\author{
Sprawność manualna \\ Posługuje się przy rysowaniu i innych czynnościach zawsze tą samą ręką. \\ Prawidłowo trzyma przybory i stosuje odpowiedni nacisk podczas rysowania. \\ Kreśli znaki literopodobne i podejmuje próby pisania. \\ Kolorując, mieści się w konturze. \\ Sprawnie posługuje się nożyczkami. \\ Podejmuje i samodzielnie wykonuje prace plastyczno-konstrukcyjne.
}

\title{
Wiedza o otoczeniu społeczno-przyrodniczym
}

Podaje swoje imię i nazwisko, zna swój adres zamieszkania.

Potrafi wymienić członków swojej rodziny (imiona, nazwiska, czynności zawodowe, miejsce pracy rodziców).

Wie, jaka jest teraz pora roku, nazywa poprzednią i następną.

Wie, jaki jest dzisiaj dzień tygodnia, jaki był wczoraj i jaki będzie jutro.

Potrafi powiedzieć, jaka jest dzisiaj pogoda.

Wymienia nazwy miesięcy w odpowiedniej kolejności.

\section{Umiejętności w zakresie rozwoju społeczno-emocjonalnego}

Uczestniczy we wszystkich zajęciach proponowanych przez nauczyciela.

Przestrzega zasad ustalonych w grupie.

Używa form grzecznościowych.

Współdziała z innymi dziećmi podczas zabawy i wykonywania zadań.

Wykonuje przyjęte na siebie obowiązki i doprowadza pracę do końca.

Nazywa emocje i uczucia swoje i innych osób.

(Diagnoza przedszkolna 6-latka)

Warto przeanalizować ten zestaw cech, które mają charakteryzować dziecko gotowe do rozpoczęcia szkolnej edukacji. Ponownie bowiem możemy zidentyfikować elementy schematu, który został opracowany na potrzeby opisu osiągnięć rozwojowych dziecka w różnych sferach, które mają stanowić dobre przygotowanie do nauki czytania, pisania, liczenia, a także funkcjonowania społeczno-emocjonalnego w szkole. W zakresie umiejętności manualnych dominuje obraz dziecka przestrzegającego poprawności czynności manualnych, tylko jeden punkt zakłada oczekiwanie samodzielności w wykonywaniu działań konstrukcyjno-plastycznych. Obraz prawidłowego rozwoju społeczno-emocjonalnego to ścisłe podporządkowanie nauczycielowi i bezkonfliktowa współpraca oraz przestrzeganie zasad grupowych. Zgodnie z tym podejściem proces adaptacji do szkoły jest rozumiany jako bierne przystosowanie i nie będzie miał prorozwojowego charakteru (Michalak 2019: 12).

Opisane przykłady standaryzacji edukacyjnej, widoczne w procesie komunikacji na lekcji oraz w podstawach programowych i materiałach przeznaczonych do monitorowania rozwoju dziecka, wskazują, jak wąsko i powierzchownie podchodzi się do funkcji edu- 
kacji, jak schematycznie również opisuje się postępy rozwojowe dziecka. Ta charakterystyka tworzy obraz dziecka poddany fragmentaryzacji, wyodrębniono bowiem kategorie opisu jego funkcjonowania, które tworzą niespójny, arbitralnie dobrany zestaw umiejętności. Warto w tym miejscu zwrócić uwagę na fakt, że dominująca od wielu lat w polskiej edukacji konieczność systemowego sprawdzania gotowości szkolnej i wyznaczanie uwarunkowanych podstawą programową norm, tworzących zestaw oczekiwanych od dziecka umiejętności, ma szkolnocentryczny charakter. Dziecko staje się przedmiotem zabiegów normalizacyjnych, a jeżeli nie mieści się w tej arbitralnie określonej normie, podlega selekcji albo procesowi medykalizacji (Chodyna-Santus 2017). Zatem odracza się podjęcie szkolnej edukacji albo poddaje dziecko oddziaływaniom terapeutycznym, gdy odbiega ono od zadekretowanej dla tej grupy wiekowej normy, np. jest aktywne, spontanicznie reaguje, zadaje pytania, przeciwstawia się nauczycielowi. Co ciekawe, w polskim systemie edukacji nie zwraca się uwagi albo w niewielkim zakresie obdarza się zainteresowaniem dzieci, które wykraczają ponad przewidzianą normę (por. Męczkowska-Christiansen, Zdanowicz-Kucharczyk 2019). Dobrze opanowane umiejętności czytania czy liczenia u dzieci rozpoczynających szkolną edukację nie stanowią podstawy do indywidualizacji nauczania. Proces edukacji regulują wytyczne podstawy programowej, która ujednolica, normalizuje wymagania. Jak podkreśla Maria Groenwald: „zadaniem uczniów jest dopasować się do tego stroju, a zadaniem nauczyciela - wtłoczyć ich do niego, czyli tak ukształtować, by przyglądający się edukacji postronni obserwatorzy odnieśli wrażenie, że strój i uczniowie tworzą idealną jedność" (Groenwald 2013: 136). Dziecko, wobec którego formułowane są oczekiwania ograniczone do standardu, staje się obiektem oddziaływań nastawionych na określony z góry wynik, ma dążyć do osiągnięcia wyznaczonych zewnętrznie celów i jest rozliczane z osiągania norm (Groenwald 2011: 68).

\section{Kierunek zmian}

Czy można to zmienić? Wymaga to weryfikacji podejścia do roli i zadań edukacji, rozumienia procesu uczenia się. Proces nauczania i bycia uczącym się - to nie jest spoglądanie przez lustro pojęć na świat zewnętrzny, to nie może być hierarchiczny układ nauczyciel-uczeń. Uczenie się to bycie w środku świata, wewnątrz procesu poznawania, a także w relacji z innymi w określonym kontekście edukacyjnym. Wiedza nie ma charakteru izolowanego, niezależnego, jedynie prawdziwego. Ulega dynamicznym zmianom i może być kształtowana w procesie interakcji społecznych.

W procesie uczenia się kluczowe miejsce zajmuje interakcja ze światem, bycie w nim, współzależność i szukanie sposobów zmieniania jego rozumienia i strategii działania, a to przeczy standaryzowanemu podejściu. Pojęcie wiedzy na gruncie psychologii poznawczej uległo dawno przedefiniowaniu z zasobu informacji na proces dochodzenia do nich, co otwiera drogę do uznania różnorodności sposobów ich zdobywania (Neisser 2014). Zastanawia jednak, jak w edukacji jest ciągle silna tendencja do ograniczania różnorodności, a w zamian - do celebrowania różnych form standaryzacji i upraszczania praktyki 
edukacyjnej. Dahlberg, Moss i Pence podkreślają, że: „(...) Sen o zbudowaniu fundamentów, które mogłyby utrzymać ciężar uniwersalnych prawd i pewności - w odniesieniu do rozumienia rozwoju dzieci, poznania elementów wysokiej jakości opieki, oceny środowiska, przewidywania rezultatów osiąganych przez dzieci i wielu innych - nigdy nie był niczym więcej niż tylko snem. Snem zrodzonym z obietnicy nowoczesności” (Dahlberg i in. 2013: 273). Tkwienie w tym iluzorycznym obrazie znormalizowanej edukacji, znormalizowanego rozwoju nie stanowi bazy do zmiany czy postępu. Potencjał rozwojowy jest zawarty w różnorodności, w odmiennych sposobach rozumienia siebie i świata, w wymianie doświadczeń, perspektyw i punktów widzenia, w zainteresowaniu odmiennością spojrzenia. Ta różnorodność rozwojowa jest szczególnie wyraźnie widoczna u dzieci przekraczających próg szkoły. A zatem nauczycielska, nieformalna diagnoza edukacyjna, rozumiana jako proces monitorowania indywidualnego rozwoju dzieci, nabiera szczególnego znaczenia. Jednak w polskiej edukacji wczesnoszkolnej ten rodzaj diagnozy jest - jak podkreśla Szyling (2019) - w stanie atrofii czy zaniechania. Zaniedbania dotyczą: braku diagnozowania dziecięcych potrzeb i zainteresowań, obserwacji ich aktywności podczas wykonywania zadań szkolnych, rezygnacji z podejmowania wysiłku opracowania nauczycielskich form sprawdzania umiejętności uczniów w konkretnym kontekście klasowym, a w szczególności tych poza standardami. Należy dążyć do podniesienia rangi diagnozy wewnętrznej w ujęciu interpretatywnym, a nie obiektywistycznym (Groenwald 2011: 57). Podjęcie tego zadania wymaga profesjonalnego przygotowania i przede wszystkim refleksyjnego podejścia do własnej praktyki edukacyjnej. A to wymaga poczucia autonomii nauczycieli i jednocześnie merytorycznego wsparcia, ale opartego na współdziałaniu, a nie kontroli i rozliczaniu z wykreowanych przez ,ekspertów” efektów. Groenwald zauważa jednak istnienie zjawiska upodabniania się diagnozy „,wewnętrznej” w klasie szkolnej do zewnętrznych diagnoz, co powoduje, że nauczyciele „(...) zgodnie z nimi uczestniczą w kreowaniu abstrakcyjnego i pozornego wizerunku szkoły - dzieła diagnostycznej mistyfikacji” (Groenwald 2011: 73).

Konieczna jest zmiana myślenia o rozwoju i edukacji dzieci w kategoriach założonych efektów i etapów, a więc niejako od końca. W to miejsce Hillevi Lenz Taguchi przyjmuje perspektywę eksponującą społeczną naturę konstruowania wiedzy, kładzie nacisk na pogłębianie rozumienia tego, co teraz się dzieje w dialogu i w refleksyjnej analizie z innymi, z akceptacją tymczasowości i niepewności (Taguchi 2010: 29-30). Wyraża się to w odejściu od:

- formułowania skończonych celów i wartości zewnętrznych do ich tworzenia w wyniku współpracy i renegocjacji;

- indywidualnej odpowiedzialności za proces uczenia się do wzajemnej współpracy i wspólnej odpowiedzialności;

- identyfikowania braków i zaburzeń po afirmację różnorodności;

- ujęcia inkluzji jako włączania czegoś marginalnego do centralnego po inkluzję jako wzajemne przekształcanie i negocjację wartości i celów. 
Ten inkluzyjny paradygmat zakłada: brak izolacji od świata zewnętrznego, bycie w nim w procesie uczenia się, negocjowanie celów w zmiennym kontekście społecznym i kulturowym. W konsekwencji powoduje to, że dziecko nie jest dopasowywane do określonych struktur i ram. To potrzeby uczących się wyznaczają określony, elastyczny porządek sytuacji i praktyk edukacyjnych. W inkluzyjnym paradygmacie uczący się jest wewnątrz działania, a nie na zewnątrz, nie jest obiektem oddziaływania, ale podmiotem w działaniu poznawczym.

Można w tym miejscu odwołać się do rozróżnienia funkcji edukacji wprowadzonego przez Gerta Biestę. Wyodrębnił on dwie związane ze sobą funkcje: kompetencyjną i socjalizacyjną, oraz trzecią, będącą w opozycji do dwóch wymienionych - upodmiotowienia (Biesta 2006: 73). Funkcja kompetencyjna zakłada osiągnięcie określonej wiedzy, dyspozycji i umiejętności, dających kwalifikacje do podejmowania określonych zadań, ról społecznych. Funkcja socjalizacyjna umożliwia sprawne wprowadzenie w określony układ i porządek kulturowy i społeczno-polityczny. Obie te funkcje, zdaniem Biesty, mają funkcjonalny i instrumentalny charakter. Są też pozbawione ryzyka, mają bowiem ściśle wyznaczone efekty kształcenia, z góry zaplanowany punkt dojścia, czyli standardy. Edukacja ma być mocna, ale i bezpieczna oraz przede wszystkim przewidywalna, podporządkowana standaryzowanym instrumentom kontroli. Takie oczekiwania wobec szkoły formułują: politycy, opinia publiczna, media, a także organizacje międzynarodowe, np. OECD, uznając, że edukację można poddać ścisłej kontroli. Dlatego, zdaniem Biesty, postrzeganie edukacji w kategoriach przyczynowo-skutkowych zjawisk, gdzie efekty uczenia się tworzą fundament myślenia o szkole oznacza de facto pozbawienie jej kontaktu z rzeczywistością (Biesta 2010: 20). W zamian kreowana jest sztuczna rzeczywistość, przewidywalna i kontrolowana. Alternatywą dla tych dwóch funkcji edukacji utrwalających status quo jest upodmiotowienie, a więc wyjście poza tę przewidywalną, standaryzowaną rzeczywistość i wkroczenie w realny świat, który wymaga całościowego, holistycznego poznawania. Taka funkcja edukacji nie ma za zadanie „lokowania świata w uczniach", ale umożliwia im budowanie własnej tożsamości, stawanie się w świecie. Jaki praktyczny wymiar może mieć takie podejście pedagogiczne, to ujawni się w przyszłości. Na razie tkwimy w okowach standaryzacji!

\section{Literatura}

Biesta G.J. (2006), Beyond Learning. Democratic Education for a Human Future. London, New York, Routledge, Taylor and Francis Group.

Biesta G.J. (2010), Good education in an age of measurement. London, Routledge.

Burman E. (2010), Between two debts: child and (inter) national development. W: N. Yelland (ed.), Contemporary perspectives on Early Childhood Education. Berkshire, Open University Press.

Chodyna-Santus M. (2017), Medykalizacja niepowodzeń szkolnych a rynek ustug terapeutycznych. Kontrowersje wokót metod terapii. „Przegląd Pedagogiczny”, 2(14). 
Dagiel M., Żytko M. (red.) (2009), Badanie umiejętności podstawowych uczniów klas trzecich szkoty podstawowej. Nauczyciele kształcenia zintegrowanego - wiele różnych światów. Warszawa, Centralna Komisja Egzaminacyjna.

Dahlberg G., Moss P., Pence A. (2013), Poza dyskursem jakości w instytucjach wczesnej opieki i edukacji. Wrocław, Wydawnictwo Naukowe Dolnośląskiej Szkoły Wyższej.

Dąbrowski M. (2013), (Za) trudne, bo trzeba myśleć? O efektach nauczania matematyki na I etapie kształcenia. Warszawa, Instytut Badań Edukacyjnych.

Dąbrowski M., Żytko M. (red.) (2008), Badanie umiejętności podstawowych uczniów klas trzecich szkoły podstawowej. Konteksty szkolnych osiagnięć uczniów. Raport z badań ilościowych. Warszawa, Centralna Komisja Egzaminacyjna.

Diagnoza przedszkolna 6-latka. Arkusz badania gotowości dziecka do podjęcia nauki w szkole. Karta dziecka. https://podrecznikarnia.pl/images/6-latki/pliki/Diagnoza_6_latka._Karta_dziecka. pdf, 3.04.2020.

Groenwald M. (2011), Diagnostyka edukacyjna ,w” $i$,,wobec” szkolnej rzeczywistości. „Forum Oświatowe", 45(2).

Groenwald M. (2013), Standardy moralne czy standardy wymagań? O moralnych aspektach pozoru w szkole. W: M. Dudzikowa, K. Knasiecka-Falbierska (red.), Sprawcy i/lub ofiary działań pozornych w edukacji szkolnej. Kraków, Oficyna Wydawnicza „Impuls”.

Klus-Stańska D. (2015), Wyjść poza instytucjonalna standaryzację dziecka. Nowe inspiracje teoretyczne dla wczesnej edukacji. „Studia Pedagogiczne”, 68.

Męczkowska-Christiansen A., Zdanowicz-Kucharczyk K. (2019), Uczeń zdolny w perspektywie dyskursu produktywnego. Cz. II: Świat szkoły. „Problemy Wczesnej Edukacji”, 4(47).

Michalak R. (2019), Psychospoleczna perspektywa adaptacji szkolnej dzieci-konceptualizacja zjawiska. „Problemy Wczesnej Edukacji”, 2(45).

Neisser U. (2014), Cognitive psychology. New York, Psychology Presse.

Rozporządzenie Ministra Edukacji Narodowej z dnia 14 lutego 2017 r. w sprawie podstawy programowej wychowania przedszkolnego oraz podstawy programowej kształcenia ogólnego dla szkoły podstawowej, w tym dla uczniów z niepełnosprawnością intelektualną w stopniu umiarkowanym lub znacznym, kształcenia ogólnego dla branżowej szkoły I stopnia, kształcenia ogólnego dla szkoły specjalnej przysposabiającej do pracy oraz kształcenia ogólnego dla szkoły policealnej (Dz.U. poz. 356). http://prawo.sejm.gov.pl/isap.nsf/download.xsp/WDU20170000356/O/D20170356.pdf, 6.04.2020.

Szyling G. (2019), Atrofia nieformalnej diagnostyki edukacyjnej we wczesnej edukacji. Między biernościq a przemoca poznawcza w epoce ekspertów. „Problemy Wczesnej Edukacji”, 4(47).

Taguchi L.H. (2010), Rethinking pedagogical practice in early childhood education: a multidimensional approach to learning and inclusion. W: N. Yelland (ed.), Contemporary perspectives on Early Childhood Education. Berkshire, Open University Press.

Żytko M. (2010), Pozwólmy dzieciom mówić i pisać - w kontekście badań umiejętności językowych trzecioklasistów. Warszawa, Centralna Komisja Egzaminacyjna.

Żytko M. (2015), Edukacja językowa w szkole - między dążeniem do formalizacji schematu a refleksja nad uczestnictwem $w$ zdarzeniach komunikacyjnych. W: D. Klus-Stańska (red.), (Anty) edukacja wczesnoszkolna. Kraków, Oficyna Wydawnicza „Impuls”. 